\title{
Climate change impacts on rainfed agriculture in the Guadiana river basin (Portugal)
}

\author{
Pedro Valverde ${ }^{\mathrm{a}, \mathrm{b}}$, Mário de Carvalho $^{\mathrm{b}}$, Ricardo Serralheiro ${ }^{\mathrm{b}, *}$, Rodrigo Maia $^{\mathrm{c}}$, \\ Vanessa Ramos ${ }^{\mathrm{a}, \mathrm{c}}$, Bruno Oliveira ${ }^{\mathrm{a}, \mathrm{c}}$ \\ a Project FCT-PTDC/AAC-AMB/115587/09, Lisboa, Portugal \\ b ICAAM, Institute of Agricultural and Environmental Sciences, University of Évora, Évora, Portugal \\ ${ }^{c}$ FEUP, Engineering Faculty, University of Porto, Porto, Portugal
}

\section{A R T I C L E I N F O}

\section{Article history:}

Received 21 July 2014

Accepted 16 November 2014

\section{Keywords:}

Climate change

Rainfed agriculture

Water balance

Crop yields

Guadiana river basin

\begin{abstract}
A B S T R A C T
In this study, the crop yield response of rainfed crops to climate change was evaluated focusing on the most representative crops in the Guadiana river basin. The quantification of crop yields was performed using a simple soil water balance model framework. The herbaceous crop yields were evaluated with the ISAREG model, implementing a water balance approach combined with the Stewart method. A similar water balance approach was used to estimate the yields for the most representative permanent rainfed woody crops in the region using an alternative spreadsheet-based model, but implementing a more detailed water stress evaluation through the crop cycles. Yields were simulated for two future periods (2011-2040) and (2041-2070) using, as climate inputs, temperature and precipitation series, reflecting a combination of five climate change scenarios (CCS) created using the ensemble-delta technique applied to CMIP3 climate projections datasets to represent different alternative climate change bracketing conditions for rainfall and air temperature. The results showed that comparatively with the reference period climate (1961-1990) rainfed crop yields will decrease in future period 1 (2011-2040) and reach even higher losses in future period 2 (2041-2070). Within the herbaceous crops, sunflower and winter wheat were the most susceptible to yield losses under climate change, reaching estimated maximum losses for future period 2 of respectively $18.5 \%$ and 13.6\%, followed by natural grown pastures with $11.5 \%$. For woody crops, maximum estimated yields losses were considerably higher for almond (27.2\%) than grapevine (5.4\%) and olive (14.9\%).
\end{abstract}

(C) 2014 Elsevier B.V. All rights reserved.

\section{Introduction}

The Guadiana river basin constitutes one of the three main drainage units of the Iberian Peninsula shared between Portugal and Spain. Enclosed in the Mediterranean region with semiarid and sub-humid conditions, it is particularly vulnerable from the agricultural viewpoint to small changes in temperature and precipitation, due to its characteristic sub-tropical transitional climate, characterized by hot and dry summers with high rates of atmospheric demand and mild winters with irregular rainfall. The climate change characterization in Portugal elaborated in the SIAMII report (Santos and Miranda, 2006) compiling the results from a wide range of General circulation models (GCM) and Intergovernmental Panel on Climate Change (IPCC) $\mathrm{CO}_{2}$ emission

\footnotetext{
* Corresponding author. Tel.: +351 266967009.

E-mail address: ricardo@uevora.pt (R. Serralheiro).
}

scenarios (SRES) foresees an increase of average air temperature in Portugal. The intensity and robustness of the climate change signals produced by a range of global and regional climate models suggest that the Mediterranean might be an especially vulnerable region to global change (Filippo and Piero, 2008). The climate trends observed in the last decades in the region suggest that climate conditions are moving towards a more arid climate typology with an increase in mean air temperature, reduction in total annual precipitation, changes in rainfall seasonal distribution and higher intensity and frequency of extreme weather events (Santos and Miranda, 2006; Valverde et al., 2014). These climate trends suggest that future climate conditions will potentially intensify existing crop water stress setting new potential threats to the agricultural sector, primarily in rainfed farming conditions, adding up concerns over yield return under rainfed conditions and, therefore, its economic viability.

In the context of climate change impacts, the contribution of rainfed agriculture for food security should not be underestimated 
as it currently supplies some 58 percent of the world's food production (Rosegrant et al., 2002), including most of the production of cereals and legumes, as well as the largest share of fodder and pastures, important for managing local livestock. At basin scale, and most markedly in the Alentejo plains region, rainfed agriculture comprises cereal fields and extensive pastures for livestock production with a relevant regional socio-economic importance. Additionally olive oil and wine are some of the most important rainfed agricultural products in the Guadiana river basin region, representing an important economical component of national agricultural exports. Although the yields of these crops are lower under rainfed agriculture than with their irrigated equivalents, they are often credited to have differentiated properties that tend to enhance their market value. Almonds are also an important crop in this basin, most markedly in the Algarve region, supporting the manufacture of a wide range of regional products.

The Alentejo and Algarve regions are partially enclosed in the Portuguese part of the Guadiana river basin, comprising an extensive area with agriculture traditionally developed under rainfed conditions. The development of the Alqueva dam and its vast irrigation network, presently under its final stages of completion, may determine an important change in paradigm in the region's agricultural sector, solving some of its cyclic water shortage limitations that had historically inhibited the adoption of irrigation. However rainfed agriculture still maintains a larger share in the region and, therefore, important in many ecological and economic contexts.

In the last decades, farmers in the Guadiana river basin have endured adverse effects due to climate change, mostly resulting from extreme events, particularly prolonged droughts, threatening not only the traditional food crops such as wheat, but also livestock feed crops. These climate events have often caused significant impacts on local economy, requiring government intervention to compensate for the climate-related agricultural losses.

\section{Materials and methods}

\subsection{Description of the study area}

The study area is located in the hydrological basin drained to the Guadiana River, southern Portugal. It was divided in six units of analysis (UA), defined by the main sub-basins of the tributaries of the Guadiana River, as shown in Fig. 1. This spatial definition was adopted from previous works performed under a pilot project for the development of a Portuguese Drought Forecasting and Management System (hereafter referred to as SPGS Project, following the Portuguese acronym) (Serralheiro et al., 2010; Vivas et al., 2010; Vivas and Maia, 2010) and was used to allow an enhanced spatial resolution of climatic heterogeneities and hence provide a better assessment of crop yield impacts.

Table 1 summarizes the current crop area distribution under rainfed agriculture in the Guadiana basin, for the most locally representative set of crops, as described by the 2009 national agricultural census (INE, 2011). Despite the increasing interest of farmers in irrigation, rainfed agriculture still maintains greater representativeness in the region, totalling, for the representative set of crops considered, more than 634000 ha, of which about $66 \%$ are pastures for livestock grazing. Wheat and other winter grain cereals, olive trees and grapevines, grown mainly for winemaking, are some of the most representative rainfed crops in the Guadiana river basin, while almond trees are particularly important in the southern region (UA6). As can be observed in Table 1, land use varies substantially within the basin. To some extent, it may be related to natural factors, as geology, soils, and climate, but the main reasons for land use forms are political and historic in nature.

\subsection{Climate change scenarios (CCS)}

Five climate change scenarios (CCS 1 to 5 ) were produced based on the Global climate model output from the World Climate Research Programme's (WCRP's) Coupled Model Inter-comparison Project phase 3 (CMIP3) multi-model dataset (Meehl et al., 2007), obtained from www.engr.scu.edu/ emaurer/global_data/. This dataset was downscaled as described by Maurer et al. (2009) using the bias-correction/spatial downscaling method (Wood et al., 2004) to a 0.5 degree grid, based on the 1950-1999 gridded observations of Adam and Lettenmaier (2003). The CMIP3 climate simulations datasets used in this study include the outputs of 16 IPCC Models under 3 future emissions scenarios (A2, A1B, B1, resulting in a total of 48 different climate simulations containing monthly records of both precipitation and temperature at a $0.5^{\circ}$ spatial resolution for the period from 1950 until 2099. The bias-corrected and downscaled air temperature and rainfall simulations, for the Guadiana river basin $\left(40.5^{\circ} \mathrm{N}\right.$ to $37^{\circ} \mathrm{N}$ lat.; $1.5^{\circ} \mathrm{W}$ to $8.5^{\circ} \mathrm{W}$ long.), were extracted from the referred to database. The simulations for the Guadiana river basin advocate that future climate will produce overall hotter and drier conditions, worsening the semi-arid local climate features (Fig. 2).

For definition of the five climate change scenarios, the selection of a historical reference period from 1961-1990 was essential, along with two future periods: 2011-2040 (future 1), and 2041-2070 (future 2). The CCS were generated for each future period, using a period-change approach (evaluation of the period mean-annual rainfall and air temperature changes, between the historical and future period) (Reclamation, 2009). To represent future possibilities and bracket uncertainty, four of the five climate change scenarios considered in this study (CCS 1, 2, 4 and 5) were defined so as to enclose different ranges (percentile of changes) of air temperatures and precipitation, with one hot and dry scenario (CCS 3), representing the central tendency of these projected climate variables. Table 2 summarizes, for each simulation period and CCS, the bracketing conditions for mean air temperature $T_{m}\left({ }^{\circ} \mathrm{C}\right)$ and total annual precipitation $P(\mathrm{~mm})$ generated from the ensemble of climate projections and its corresponding value range variation for each percentile rank of projected period-mean temperature and precipitation changes (Reclamation, 2011).

The definition of CCS was performed to support the development of climate inputs (the so-called climate-adjusted weather, CAW, series) for the crop irrigation model (ISAREG) using the Ensemble Delta technique, which reflects periodic changes in monthly mean temperature and rainfall over the studied region from an ensemble of climate projections (Reclamation, 2009). The ensemble-delta technique comprises the calculation of 12-monthspecific change factors for both precipitation and air temperature, for each cell, and for each CCS. These change factors were applied to the 30 years-observed climate series of the historical reference period (1961-1990) to develop the CAW series.

Thus, the generated CAW series (developed for each CCS) replicate, for future periods, the historic inter-annual variation pattern contained in the underlying historical baseline reference data, whilst inducing a monthly and annual variation in the generated climate time series, therefore assuming a realistic monthly and annual variation evolution over the generated climate time series based on the past climate evolution.

The five CCS outputs were built with different thresholds, resulting, comparatively to CCS 3 , in lower absolute values of the temperature for CCS 1 and 2, and higher temperatures for CCS 4 and 5. The outputs of all CAW series (reflecting each one 


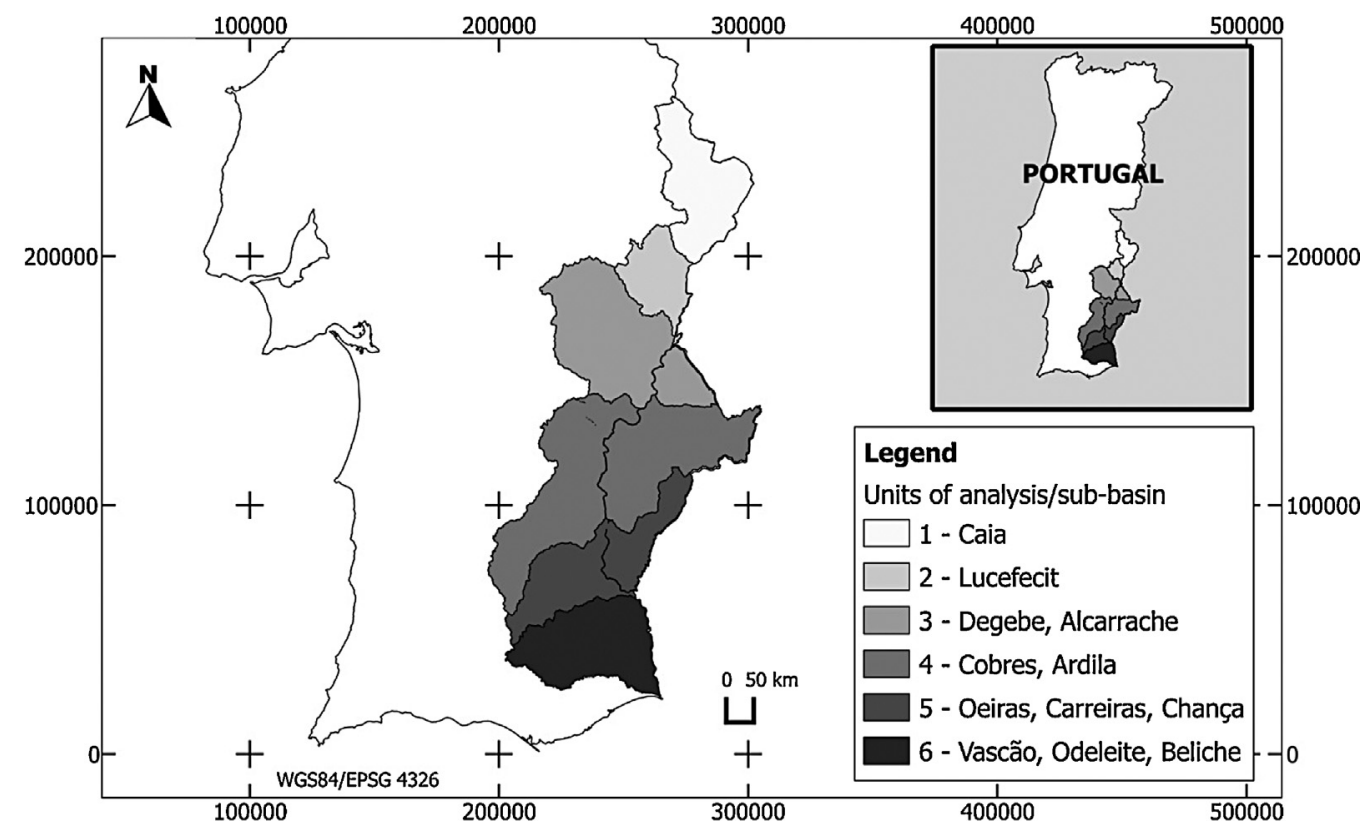

Fig. 1. Study site: Guadiana river basin and spatial units of analysis (UA).
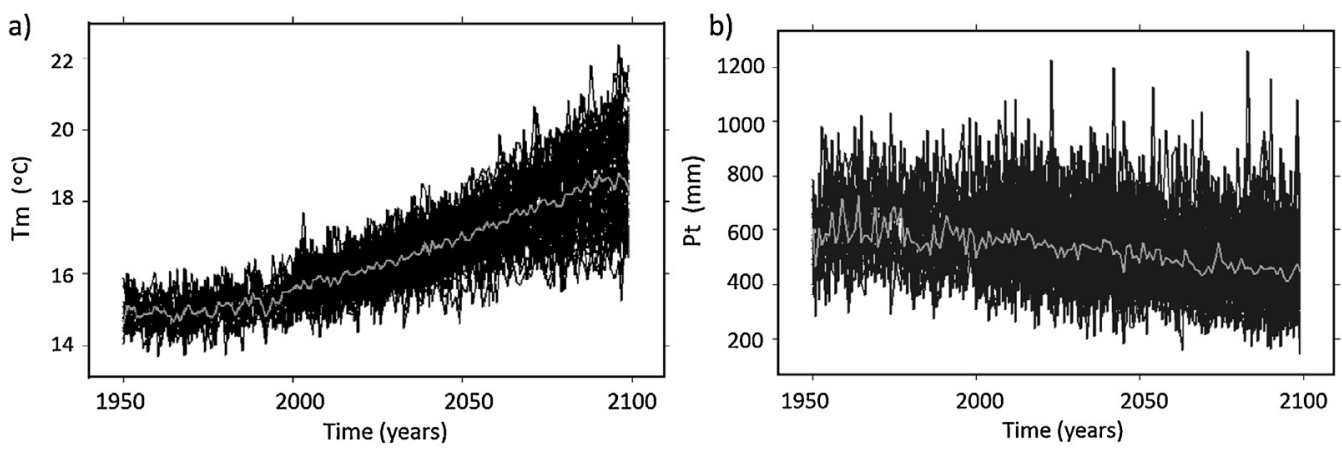

Projected simulations

_ Ensemble annual median

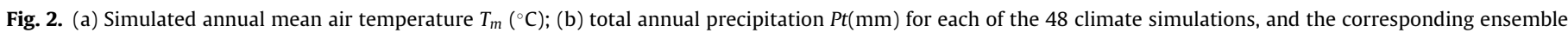
annual median for the Guadiana river basin.

of the developed CCS) display similar time-evolution tendencies, exhibiting a rising tendency for minimum, maximum and mean air temperatures $\left(T_{\min }, T_{\max }\right.$ and $\left.T_{m}\right)$, but decreasing thermal amplitude $\left(T_{\max }-T_{\min }\right)$. Fig. 3 shows the CAW monthly average air temperatures $\left({ }^{\circ} \mathrm{C}\right)$ generated for the central tendency scenario (CCS 3 ), considering the spatial average of the 6 spatial units defined for the Guadiana basin as depicted in Fig. 1. Taking the central tendency (CCS 3) CAW series shown in Fig. 3(a) and (b) as an example to illustrate the CAW series (for each CCS) tendencies for both future period 1 (2011-2040) and future period 2 (2041-2070), the monthly air temperatures describe a rising tendency, with highest monthly values of mean air temperature $T_{m}$ reaching $27.5^{\circ} \mathrm{C}$ for future period 1 and $28.5^{\circ} \mathrm{C}$ for future period 2 . Comparing the monthly temperatures of both 30 -year future periods 1 and 2, the model predicts that the upper values of minimum air temperatures will rise at a faster rate of $0.7^{\circ} \mathrm{C}\left(21.7\right.$ to $\left.22.4^{\circ} \mathrm{C}\right)$ than the $0.6^{\circ} \mathrm{C}$ increase rate for maximum temperatures ( 33.9 to $34.5^{\circ} \mathrm{C}$ ), indicating that the climate model predicts that the extreme values of

Table 1

Summary of rainfed crop areas distribution for each UA in the Guadiana basin (ha) (INE, 2011).

\begin{tabular}{|c|c|c|c|c|c|c|c|}
\hline & UA1 & UA2 & UA3 & UA4 & UA5 & UA6 & Total \\
\hline Wheat/winter grain cereals & 7395 & 4016 & 13557 & 41783 & 12047 & 695 & 79493 \\
\hline Grain legumes & 145 & 18 & 150 & 2188 & 1148 & 73 & 3723 \\
\hline Winter fodder & 7786 & 4040 & 12871 & 18841 & 6801 & 1488 & 51827 \\
\hline Sunflower/oleaginous & 197 & 2 & 90 & 6955 & 624 & 0 & 7868 \\
\hline Pastures & 64920 & 38029 & 111506 & 129752 & 64250 & 11070 & 419527 \\
\hline Nut trees/almond & 184 & 139 & 261 & 529 & 485 & 7366 & 8964 \\
\hline Olive groves & 8579 & 3663 & 8561 & 29752 & 5377 & 3411 & 59344 \\
\hline Grapevine & 419 & 780 & 1296 & 1218 & 49 & 159 & 3921 \\
\hline Total & 89625 & 50687 & 148292 & 231017 & 90781 & 24264 & 634667 \\
\hline
\end{tabular}


Table 2

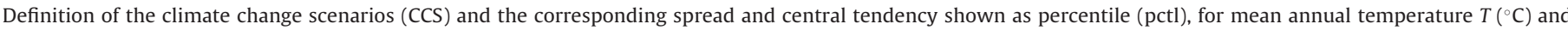
precipitation $P(\mathrm{~mm})$.

\begin{tabular}{|c|c|c|c|}
\hline Period & $\mathrm{CCS}$ & $T\left({ }^{\circ} \mathrm{C}\right)$ & $P(\mathrm{~mm})$ \\
\hline Future 1 & 1-Warm and mildly dry & 0.99 (25 pctl) & -4.89 (75 pctl) \\
\hline \multirow[t]{4}{*}{$(2011-2040)$} & 2-Warm and much dry & 0.99 (25 pctl) & $-10.70(25$ pctl $)$ \\
\hline & 3-Hot and dry (central tendency) & $1.23(50 \mathrm{pctl})$ & $-8.76(50 \mathrm{pctl})$ \\
\hline & 4-Hotter and mildly dry & 1.39 (75 pctl) & -4.89 (75 pctl) \\
\hline & 5-Hotter and much dry & 1.39 (75 pctl) & $-10.70(25$ pctl $)$ \\
\hline Future 2 & 1-Warm and mildly dry & $1.73(25 \mathrm{pctl})$ & $-9.80(75 \mathrm{pctl})$ \\
\hline \multirow[t]{4}{*}{$(2041-2070)$} & 2-Warm and much dry & $1.73(25 \mathrm{pctl})$ & $-21.79(25 \mathrm{pctl})$ \\
\hline & 3-Hot and dry (central tendency) & $2.31(50 \mathrm{pctl})$ & $-15.20(50 \mathrm{pctl})$ \\
\hline & 4-Hotter and mildly dry & $2.61(75 \mathrm{pctl})$ & $-9.80(75 \mathrm{pctl})$ \\
\hline & 5-Hotter and much dry & $2.61(75 \mathrm{pctl})$ & $-21.79(25 \mathrm{pctl})$ \\
\hline
\end{tabular}

a) Future 1

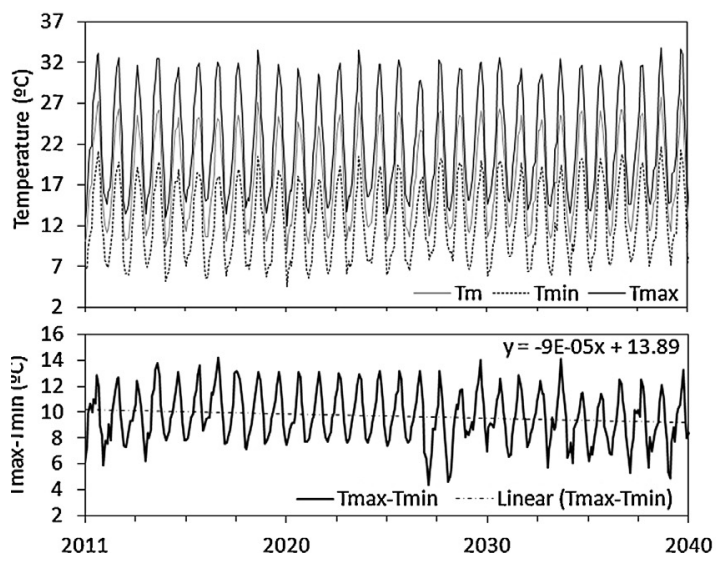

b) Future 2

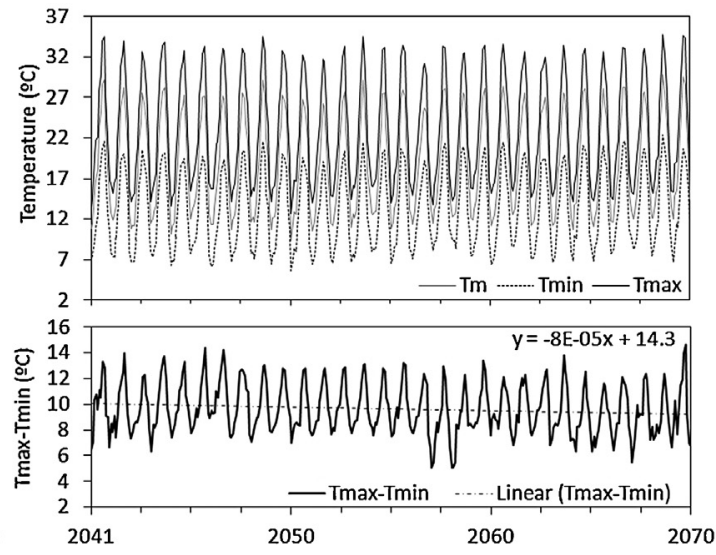

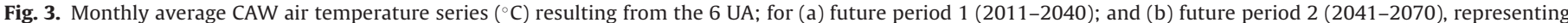
maximum $\left(T_{\max }\right)$, minimum $\left(T_{\min }\right)$, mean $\left(T_{m}\right)$ and thermal amplitude $\left(T_{\max }-T_{\min }\right)$ generated for the central tendency climate scenario $(\mathrm{CCS} 3)$.

$T_{\min }$ will rise steeper than $T_{\max }$, resulting in an overall progressive decrease of maximum thermal amplitude $\left(T_{\max }-T_{\min }\right)$.

Within each future period, 1 and 2, the decrease of thermal amplitude is shown by the negative slopes of Fig. 3(a) and (b). For the remaining CAW series (reflecting the CCS), albeit built with different thresholds resulting in lower absolute values of the temperatures for CCS $(1,2)$ and higher temperatures for CCS $(4,5)$, the outputs display similar evolution tendencies, exhibiting a rising tendency of $T_{\min }, T_{\max }$ and $T_{m}$ and decreasing thermal amplitude $\left(T_{\max }-T_{\min }\right)$.

\subsection{Crop yield response to climate change}

For herbaceous crops, the potential crop yield-loss was estimated using the ISAREG model developed at the Instituto Superior de Agronomia (ISA, Lisbon) by Teixeira and Pereira (1992) and based on the FAO methodology (Doorenbos and Pruitt, 1977; Doorenbos and Kassam, 1979), later enhanced by Allen et al. (1998). This model requires the inputs of effective precipitation (Pef), reference evapotranspiration (ETo), soil data and the characteristics of crop growth throughout the crop cycle (Teixeira, 1994). For annual crops, it was considered as input for the ISAREG model a soil depth of $0.6 \mathrm{~m}$ with total usable water capacity of $100 \mathrm{~mm}$, while for permanent crops soil conditions assumed a depth of $1 \mathrm{~m}$ and $200 \mathrm{~mm}$ usable water capacity. The ISAREG model is essentially a water balance model, which additionally implements the method proposed by Stewart and Hagan (1973) and Stewart et al. (1977) (Eq. (1)), returning the percentage of loss of production based on the relation between the actual crop evapotranspiration under rainfed conditions (ETa) and potential crop evapotranspiration under non limiting water supply (ETC). This relation can be expressed as
$(1-E T a / E T c)$, adjusted for different sensitivity coefficients to water deficit $(K y)$ during the crop cycle. The parameters $Y a$ and $Y c$ are the actual and maximum potential yields $(\mathrm{kg})$, corresponding respectively to ETa and ETC.

$$
\left(1-\frac{Y a}{Y c}\right)=K y\left(1-\frac{E T a}{E T c}\right)
$$

The crop coefficients $(K c)$ used to characterize the crops within this group are identical to those considered for irrigated crops, while the water stress coefficients $(K y)$ for each crop were based on FAO data (Doorenbos and Kassam, 1979; Allen et al., 1998).

The $K y$ approach for estimating crop yield response sum up the effects of the complex linkages between production and water use by a crop and has shown a remarkable validity to quantify the effects of water deficits on yield. The yield response coefficients (Ky) are crop specific and vary over the growing season according to growth stages, with $K y=1$ indicating that yield reduction is directly proportional to reduced water use. Values of $K y$ higher than 1 denote a crop response very sensitive to water deficit with proportionately larger yield reductions when water use is reduced under stress, whereas $K y$ lower than 1 characterize crops more tolerant to water deficit allowing partial recovery from stress but exhibiting less than proportional reductions in yield with reduced water use (Steduto et al., 2012).

Effective precipitation Pef is the fraction of the total rainfall entering the soil profile accounting for the loss of soil water intake by the effects of runoff related to local topography, soil texture and rain interception by vegetation. In this study, the effective precipitation (Pef) used as input to the ISAREG model was determined, for each unit of analysis, using the method defined by the USDA Soil Conservation Service (USDA-SCS) (Clarke, 1998) (Eq. (2)), where 
Pt is the total precipitation ( $\mathrm{mm}$ ), estimated as the area-weighted average precipitation in each unit of analysis within the Guadiana basin.

$P e f= \begin{cases}\frac{P t(125-0.2 P t)}{125} & ;(P t<250 \mathrm{~mm}) \\ 125+0.1 P t & ;(P t \geq 250 \mathrm{~mm})\end{cases}$

Reference evapotranspiration (ETo) estimates are important inputs used to define crop water requirements within a certain climate status, and therefore determinant to estimate crop yield. The modified Penman-Monteith (FAO-56 PM), developed by FAO Irrigation \& Drainage Paper No.56 (Allen et al., 1998) is currently the standard method to estimate ETo gathering wide acceptance for agricultural studies, but it is relatively high data demanding, making it impracticable to use in climate change contexts, where available datasets provide a very limited set of climate variables. Various studies found that the Hargreaves-Samani (HS) equation (Hargreaves and Samani, 1985), despite its simplicity, returns ETo results comparable to the more accurate FAO-56 PM equation (Droogers and Allen, 2002). Studies conducted by Santos and Maia (2005) comparing the linear regression results of the HS equation with the standard FAO-56 PM using data from nine automatic weather stations in the Guadiana basin, concluded that the Hargreaves-Samani equation reached an average determination coefficient of 0.9 , with two weather stations reaching almost a perfect fit $\left(R^{2}=1\right)$. This equation was also adopted successfully for the Guadiana basin in the climate change context of the SPGS project (Serralheiro et al., 2010). The reference evapotranspiration (ETo) was estimated for the six units of analysis and climate scenarios (CCS) using the HS equation for semi-arid regions (Eq. (3)), where $R a$ is the average extra-terrestrial radiation $\left(\mathrm{mm} \mathrm{day}^{-1}\right)$ and $T_{\max }$, $T_{\min }$ and $T_{m}$ are respectively the maximum, minimum and average air temperatures $\left({ }^{\circ} \mathrm{C}\right)$.

ETo $=0.0023 \mathrm{Ra}\left(T_{\max }-T_{\min }\right)^{0.5}\left(T_{m}+17.8\right)$

One exception made to the application of the ISAREG model was the estimation of fodder yields. Water requirements of winter fodder, taking oat as the reference crop, can be considered analogous to rainfed winter wheat. Experimental data (Serralheiro et al., 2010) showed that, in the Guadiana basin, yields of fodder oat can be estimated based on wheat production using Eq. (4), where $X$ is the yield of wheat (grain) in $\mathrm{kg} / \mathrm{ha}$ and $Y$ is the corresponding yield of fodder in $\mathrm{kg} / \mathrm{ha}$ (shoot dry biomass), considering oat as the reference crop.

$Y=1757.5+1.23 X$

Table 3 summarizes the water stress coefficients (Ky) and crop coefficients $(K c)$ values used in the ISAREG model as inputs to estimate crop yield response of herbaceous crops.

The crop coefficients methodology used in the ISAREG model, while being suitable for modelling annual crops, is somewhat limited for permanent woody crops due to the fact that only one average water stress coefficient is indicated for consideration throughout the crop cycle. The permanent woody rainfed crops considered in this study are well adapted to the Mediterranean climate, thus exhibiting a high tolerance to water deficit conditions and variable water stress related sensitivity along the crop cycle. The selected woody crops also have particular features that require adaptation of the Ky coefficients. Grapevine (Vitis vinifera L.) and almonds (Amygdalus communis L.), for example, have dormant periods where leaf drop causes the decline of transpiration rates, greatly reducing overall crop water requirements, thus also reducing their water stress vulnerability in those periods. Olive trees (Olea europaea L.) have inherent physiologic strategies to overcome long dry periods and are capable to reduce their transpiration rates during the highest atmospheric demand months using stomata control mechanisms (Fernández et al., 1997).
The traditional rainfed olive groves in Southern Portugal have a typical density of 100 trees/ha with $10 \mathrm{~m} \times 10 \mathrm{~m}$ spacing. The productivity of the olive grove is quite unstable due not only to the characteristics of the climate in each particular year and to being particularly sensible to spring and autumn rainfall, but also due to its inherent characteristics. In rainfed conditions, the olive tends to alternate between a year with normal or high yields and lower yields in the following year, in a bi-annual cycle. This behaviour is difficult to model and adds some uncertainty to the estimates of productivity when carried out strictly according to the climate conditions. Reference yield for rainfed olive groves in the Guadiana basin was considered to be $2000 \mathrm{~kg} / \mathrm{ha}$ ( $20 \mathrm{~kg} /$ tree) and the harvest was considered to occur during November.

The rainfed almond tree assumes a high relative economic importance in the southern Alentejo and Algarve region (UA6) with a high return value that justifies its selection into this group of representative crops. Reference yields for rainfed almond were considered to be $1000 \mathrm{~kg} / \mathrm{ha}$ and the harvest month to be September.

Rainfed grapevine in the Guadiana basin region is mostly for wine production and is harvested in September, with 50\% canopy ground cover and an estimated reference yield of $5000 \mathrm{~kg} / \mathrm{ha}$.

In order to improve the climate-yield response modelling for woody crops, an extended Stewart methodology derived model was adopted, using a multiplicative equation, allowing the assumption of varying crop sensitivity for each crop growth period (multiple Ky coefficients), instead of the ISAREG model cumulative equation approach (single $K y$ ). This methodology was implemented using a spreadsheet, consisting of a water-balance algorithm and considering a monthly potential yield loss fraction, thus allowing a better temporal description of crop sensitivity to water stress. The proposed methodology of analysis for rainfed woody crops uses a water balance approach, using as inputs the monthly averages of effective rainfall $P$ ef $(\mathrm{mm})$ resulting from the USDA-SCS method (Eq. (2)), and Hargreaves's air temperature based ETo (mm) (Eq. (3)).

The crop water requirements for maximum potential yield or crop (maximum) evapotranspiration ETc ( $\mathrm{mm}$ ) was computed as a function of reference evapotranspiration ETo $(\mathrm{mm})$ and crop coefficients $K c$ :

$E T c=K c E T o$

For each year run, the model was initiated by starting the water balance in the month immediately after harvest, assigning this month's initial conditions to total potential (yield loss $=0 \%$ ) or equivalent reference yield $(\mathrm{kg} / \mathrm{ha})$ and setting the maximum water storage capacity $S_{\max }(\mathrm{mm})$ for average soil depth and water holding capacity in the root zone. The water balance $\left(\Delta S_{m}\right)$ for each month $m$ was estimated with Eq. (6), considering the balance of the previous month $\Delta S_{m-1}$ limited by the maximum water storage capacity of the soil profile $\left(S_{\max }\right)$ :

$\Delta S_{m}= \begin{cases}\Delta S_{m-1}+P e-E T c & ; \quad\left(\Delta S_{m-1} \geq 0\right) \wedge\left(\Delta S_{m-1}+P e-E T c<S_{\max }\right) \\ P e-E T c & ; \quad\left(\Delta S_{m-1} \leq 0\right) \wedge\left(P e-E T c<S_{\max }\right)\end{cases}$

The crop water deficit $(\Delta H)$ is equivalent to ETc-ETa for each month $(m)$, and can be estimated as monthly soil water storage variation $\left(\Delta S_{m}\right)$ :

$\Delta H_{m}=\left\{\begin{array}{lll}0 & ; & \left(\Delta S_{m} \geq 0\right) \\ \left|\Delta S_{m}\right|-F r & ; & \left(\Delta S_{m}<0\right) \wedge\left(\left|\Delta S_{m}\right|<F r\right) \\ \Delta S_{m} & ; & \left(\Delta S_{m}<0\right) \wedge\left(\left|\Delta S_{m}\right| \geq F r\right)\end{array}\right.$

For conditions where $\Delta S_{m}<0$, the water deficit was computed with an attenuation ( $F r)$, set to a maximum of $15 \mathrm{~mm} / \mathrm{month}$ corresponding to the partial water refill effect in the root zone soil 
Table 3

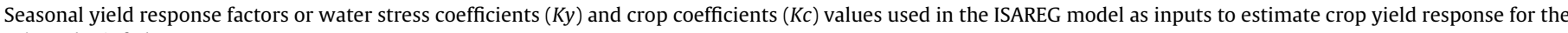
selected rainfed crops.

\begin{tabular}{|c|c|c|c|c|}
\hline \multirow[t]{2}{*}{ Crop } & \multirow[t]{2}{*}{ Ky } & \multicolumn{3}{|c|}{$K c /$ crop stage } \\
\hline & & Initial & Mid & Final \\
\hline Winter wheat & 1.00 & 0.30 & 1.15 & 0.25 \\
\hline Winter fodder & - & - & - & - \\
\hline Sunflower & 0.95 & 0.35 & 1.15 & 0.35 \\
\hline Grain legumes & 1.15 & 0.50 & 1.15 & 0.30 \\
\hline Pastures & 0.80 & 0.30 & 0.75 & 0.75 \\
\hline
\end{tabular}

* Crop yield response was estimated based on the relation observable between fodder dry matter biomass and winter wheat grain yield outputs.

Table 4

Stress coefficients $(K y)$ and crop coefficients $(K c)$ values considered for woody crops in the Guadiana basin.

\begin{tabular}{|c|c|c|c|c|c|c|c|c|c|c|c|c|c|}
\hline Crop & & Jan & Feb & Mar & Apr & May & Jun & Jul & Aug & Sep & Oct & Nov & Dec \\
\hline \multirow{2}{*}{ Grapevine $^{*}$} & $K c$ & 0 & 0.30 & 0.30 & 0.70 & 0.70 & 0.60 & 0.30 & 0.30 & 0.20 & 0.20 & 0 & 0 \\
\hline & $K y$ & 0 & 0.85 & 0.85 & 0.85 & 0.85 & 0.85 & 0.10 & 0.10 & 0 & 0 & 0 & 0 \\
\hline \multirow{2}{*}{ Almond ${ }^{*}$} & $K c$ & 0.50 & 0.90 & 0.90 & 0.70 & 0.70 & 0.65 & 0.65 & 0.40 & 0.40 & 0.20 & 0 & 0 \\
\hline & Ky & 0.70 & 1.00 & 1.00 & 0.70 & 0.70 & 0.30 & 0 & 0 & 0 & 0 & 0 & 0 \\
\hline \multirow[t]{2}{*}{ Olive $^{* *}$} & $K c$ & 0.51 & 0.51 & 0.66 & 0.61 & 0.56 & 0.51 & 0.51 & 0.51 & 0.66 & 0.66 & 0.51 & 0.51 \\
\hline & $K y$ & 0 & 0.75 & 0.75 & 0.75 & 0.75 & 0.75 & 0.10 & 0.10 & 0.75 & 0.75 & 0 & 0 \\
\hline
\end{tabular}

* Null values of $K c$ and $K y$ were considered in dormancy periods and after leaf drop.

** The Kc coefficients listed for olive are for mature groves grown under dry-farming adjusted for 100 trees/ha density.

profile from deeper layers. This fix aims to implement a simplified method to obtain a closer approximation to the real behaviour of the drought-tolerant woody crops grown under rain-fed conditions, which can establish very high gradients of water potential in their root systems overcoming the soil limitations in the studied regions, characterized by small depths and often limited by semiimpermeable layers. The resulting yield loss $\left(1-Y_{a} / Y_{c}\right)$ is returned by Eq. (1), which can be rewritten as Eq. (8) as a monthly cumulative yield loss in percentage $\left(P P_{m}\right)$ :

$P P_{m}=K y_{m} \frac{\Delta H_{m}}{E T c_{m}}$

For this model $K c$ and $K y$ coefficient values were compiled from FAO Irrigation and drainage paper no. 56 (Allen et al., 1998), and paper no. 66 (Steduto et al., 2012). The coefficients were interpolated to a monthly scale with $K c$ adjusted to meet local crop stages timing and average rainfed tree spacing. $K y$ values for almond are poorly documented in the literature, specially under rainfed conditions. On irrigated almonds, relative yield versus relative applied water data derived from several studies showed linear regressions correlation coefficients ranging from 0.87 to 0.98 , indicating a strong functional relationship between yield and applied water (Steduto et al., 2012). Therefore, for almonds $K y=1$ was assumed for the critical crop stage and interpolated for different timing and magnitudes of stress during crop stages.

Table 4 lists the monthly Ky and $K c$ values considered for rainfed woody crops in the spreadsheet implementation of the crop yield response model.

For woody crops, the yield outputs of this model were found coherent to yield losses observed in recent drought years relative to regular years. However, the lack of reliable yield records did not allow for a thorough model validation.

Historical reference yields are difficult to evaluate accurately, specifically under the scope of climate change, due to the lack of consistent long-term statistics and the influence of parallel effects linked to the technical evolution of agricultural practices and soil management. The fact that reference yields can vary locally due to soil, agricultural management practices, crop subspecies and microclimate conditions also adds complexity to the
Table 5

Reference yields ( $\mathrm{kg} \mathrm{ha}^{-1}$ year $^{-1}$ ) considered for the selected rainfed crops in the Guadiana basin, grown under close to ideal agro-climatic conditions and management practices.

\begin{tabular}{ll}
\hline Crop & Reference yield $\left(\mathrm{kg} \mathrm{ha}^{-1}\right.$ year $\left.^{-1}\right)$ \\
\hline Winter wheat & 4300 \\
Winter fodder & 7047 \\
Sunflower & 1800 \\
Grain legumes & 3500 \\
Pastures & 2000 \\
Olive & 2000 \\
Grapevine & 5000 \\
Almond & 1000
\end{tabular}

${ }^{*}$ Winter fodder reference yield (dry matter biomass) was estimated considering its dependence from winter wheat.

${ }^{* *}$ Value listed is for natural pastures (dry matter biomass). For sown pastures the reference yield is approximately double.

task of defining the referential yield. Table 5 lists, for each selected crop, the average reference yields or maximum expected yields ( $\mathrm{kg} \mathrm{ha}^{-1}$ year $\left.^{-1}\right)$ that can be achieved under rainfed farming in the Guadiana basin region, considering ideal agro-climatic conditions. Given the previously mentioned difficulties in estimating accurate reference yields, the values listed in Table 5 provide only an approximate representation of the best potential yields currently attainable by local farmers under ideal climate conditions and common management practices.

\section{Results and discussion}

\subsection{Climate trends from generated future climate scenarios}

Each of the five climate change scenarios (CCS) considered for the Guadiana river basin was generated by a combination of rainfall and air temperature period-changes (based on a historical period and two future periods) as shown in Table 2. The time-series evolution of each annual rainfall $\left(\mathrm{mmyear}^{-1}\right)$ and average daily ETo $\left(\mathrm{mm} \mathrm{day}^{-1}\right)$ series (developed based on each CCS) are shown, respectively, in Figs. 4 and 5, as the average of the 6 spatial units considered in the Guadiana river basin. 
a) Future 1

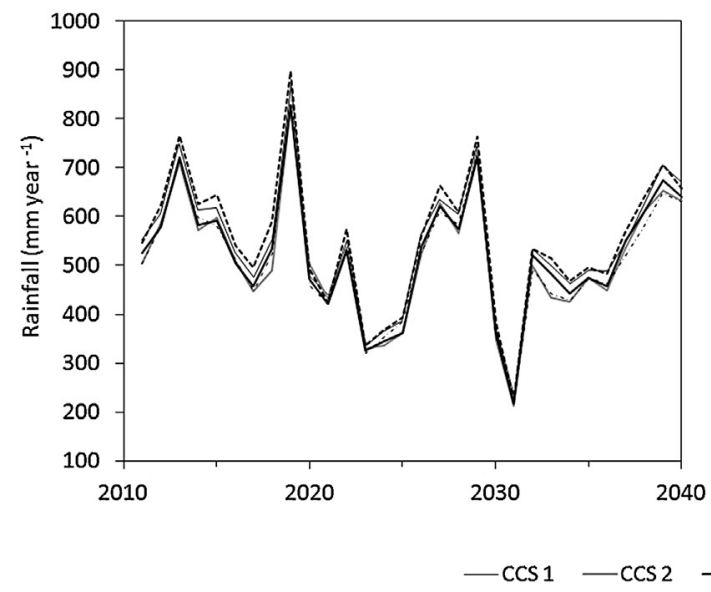

b) Future 2

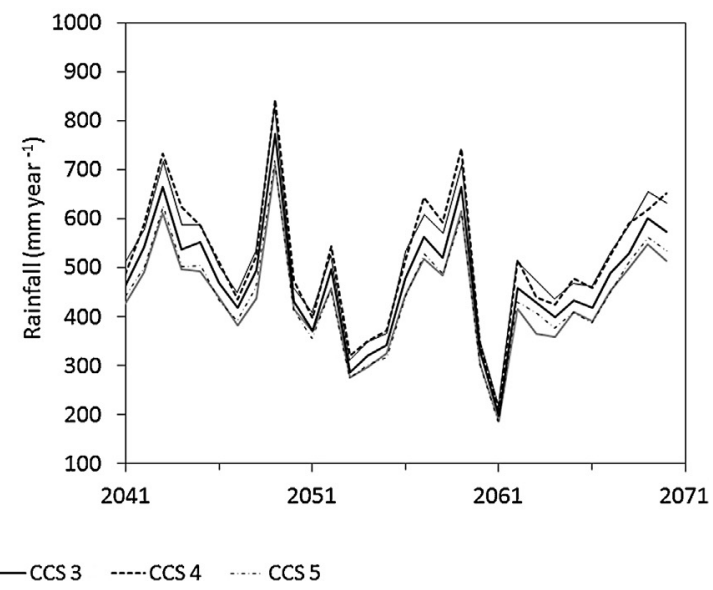

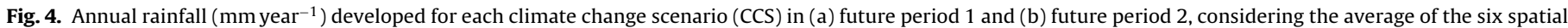
UA defined for the Portuguese Guadiana basin.

The represented future climate series show a decreasing trend in the annual total rainfall, for both future periods, which will have negative impacts on rainfed agriculture. For future period 1 , the annual rainfall projected averages are between $515 \mathrm{~mm}$ (CCS 2 and 5) and $553 \mathrm{~mm}$ (CCS 4) and under the more adverse conditions of future period 2, the annual rainfall averages are lower, falling within $438 \mathrm{~mm}$ for CCS 2 to $517 \mathrm{~mm}$ (CCS 4).

The average daily ETo determined using the temperature-based Hargreaves-Samani (HS) equation for each CCS, returned a higher atmospheric demand in future 2 (2041-2070), with an average ETo ranging from 3.29 to $3.40 \mathrm{~mm} \mathrm{day}^{-1}$, while future 1 (2011-2040) outputted an average ETo range between 3.23 and $3.27 \mathrm{~mm} \mathrm{day}^{-1}$.

One of the features identified in the CAW series is the fact that temperature series representing all the five CCS, minimum air temperature $\left(T_{\min }\right)$ rises at a faster rate than maximum air temperature $\left(T_{\max }\right)$. This resulting climate feature in the generated CAW series (developed for each CCS), causes a progressive decrease of the corresponding thermal amplitude $\left(T_{\max }-T_{\min }\right)$ used as input in the HS equation (3), determining therefore that the ETo values computed with this equation (Fig. 5) did not return, as expected, a significant trend in the ETo for the considered future periods. The term $\left(T_{\max }-T_{\min }\right)$ is used in the HS equation to account for the effects of humidity and cloudiness in the estimation of ETo (Shahidian et al., 2012; Samani and Pessarakli, 1986). Although the HS ETo results are coherent with the climate input datasets representing each CCS, under the climate change analysis context, the HS equation's inherent susceptibility to thermal amplitude in the estimation of ETo may give rise to concerns about this method's reliability in simulating ETo in future periods, requiring further calibration procedures. However, if the HS method assumptions remain valid even with climate parameters leaving present thresholds, the secondary effects derived from humidity and cloudiness being dependent on thermal amplitude may contribute to lessen the potential impacts of the model's predicted temperature increase in ETo.

\subsection{Crop yield response to climate change}

The potential effects of climate change, depending upon variations of temperature and rainfall can cause significant losses of crop yields, mostly by limiting soil water availability during the critical stages of the crop cycle. Table 6 lists the average annual rainfed crop yields $\left(\mathrm{kg} \mathrm{ha}^{-1}\right.$ year $\left.^{-1}\right)$, given the 30 -year historic climate reference period (1961-1990) and considering the representative crops selected in the Guadiana basin. The estimated yields a) Future 1

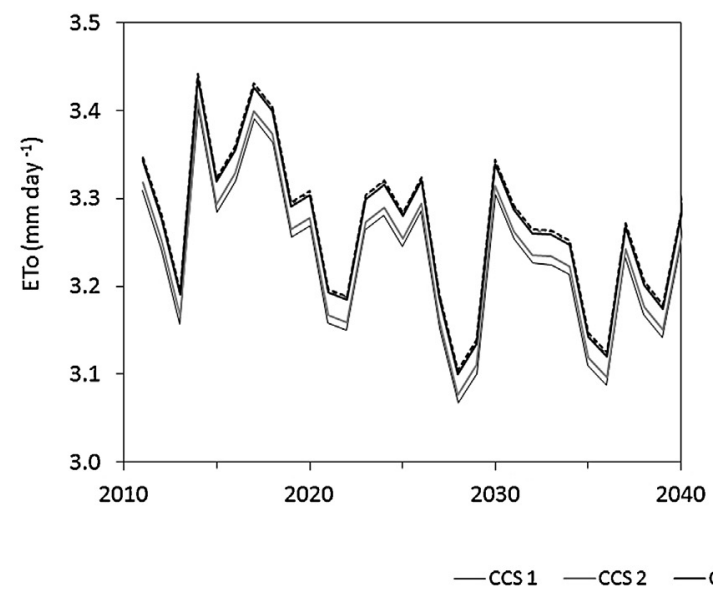

b) Future 2



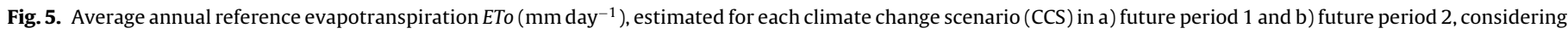
the average of the six spatial UA defined for the Portuguese Guadiana river basin. 


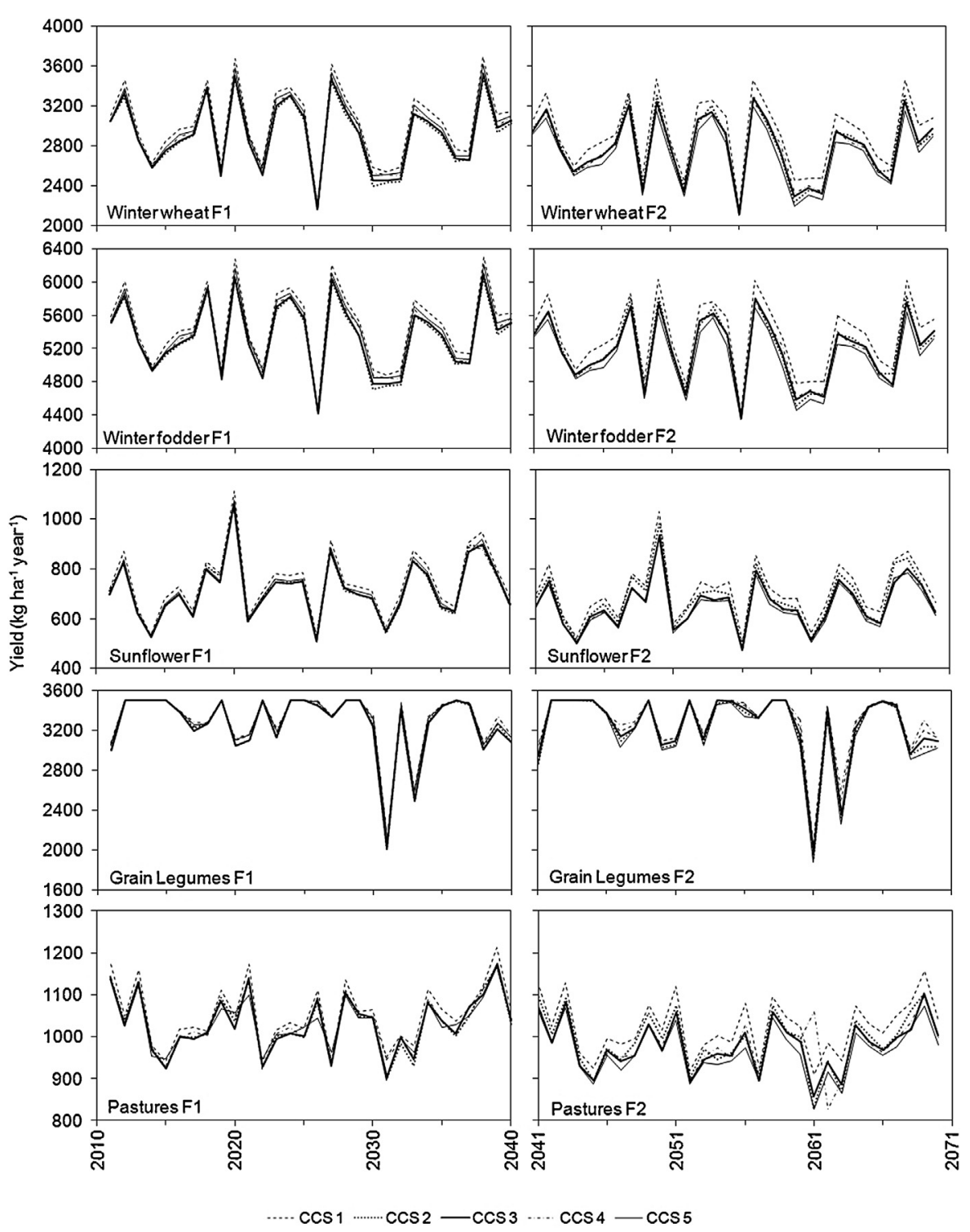

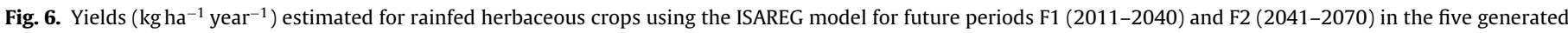

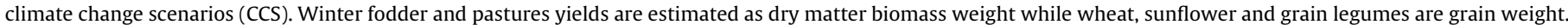

Table 6

Estimated average yields ( $\mathrm{kg} \mathrm{ha}^{-1}$ year $^{-1}$ ) for the most representative rainfed crops in the Guadiana basin in the 30-year historic climate reference period (1961-1990) with fodder and pastures yields estimated as dry matter biomass weight.

\begin{tabular}{lc}
\hline Crop & Yield $\left(\mathrm{kg} \mathrm{ha}^{-1} \mathrm{year}^{-1}\right)$ \\
\hline Winter wheat & 3145.4 \\
Winter fodder & 5626.3 \\
Sunflower & 795.3 \\
Grain legumes & 3327.1 \\
Pastures & 1091.2 \\
Olive & 1756.6 \\
Grapevine & 4889.5 \\
Almond & 713.2 \\
\hline
\end{tabular}

were determined for each crop as the reference yields (Table 5), affected by the corresponding computed yield losses (\%) returned by the crop water balance models under typical regional soil characteristics, common crop layout densities and ideal management practices.

Fig. 6 shows the future yield outputs $\left(\mathrm{kg} \mathrm{ha}^{-1}\right.$ year $\left.^{-1}\right)$ estimated with the ISAREG model for the rainfed herbaceous crops in Guadiana basin, considering the average of the outputs from the 6 spatial units of analysis defined. Fig. 7 depicts the fruit yield outputs estimated for rainfed woody crops (olive, grapevine and almond) using the spreadsheet-implemented model for the same future periods and considering an identical spatial average criteria for the Guadiana basin region. In both herbaceous and woody crops, the yields were estimated affecting the model yield loss (\%) outputs along with the reference crop yields previously listed in Table 5 .

For each crop yield result, the outputs of the period F1 (2011-2040) share a similar graphical temporal evolution shape as those of future period 2 (2041-2070), although the variation between CCS is considerably higher in future period 2 due to the larger thresholds used to generate rainfall and air temperature in the (2041-2070) climate scenarios, causing a larger dispersion of yield outputs. The larger thresholds considered in the CCS for future period 2 also tend to cause more frequent water deficit conditions, and, therefore, more pronounced yield losses, because they were generated so as to represent conditions with less rainfall and higher air temperatures than those of future period 1 .

The different combinations of rainfall and air temperature variations assumed for each of the five considered CCS affect each crop in a different manner, from the soil water balance stand point, as 


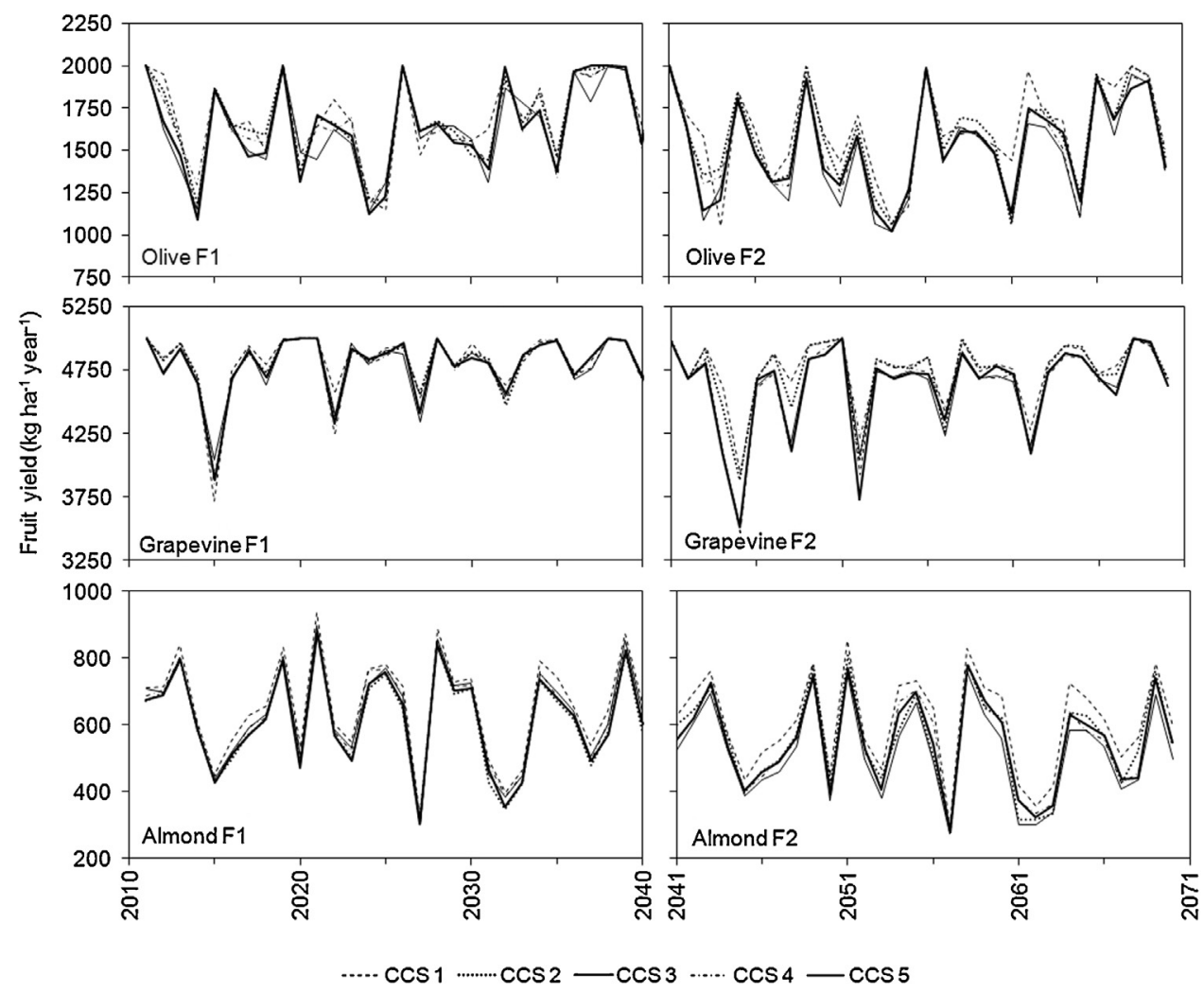

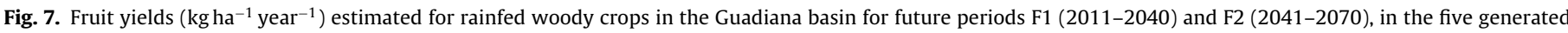
climate change scenarios (CCS), using the spreadsheet implementation of the water balance model coupled with the Stewart yield loss methodology.

soil water availability and crop water demand patterns during the crop cycle generate different yield impacts. Table 7 summarizes the 30-year average yields for each future period and CCS using, as inputs, the ETo and Pef climate data generated from each CCS, aggregating the average results from the six spatial analysis units considered for the Portuguese part of the Guadiana river basin. The yield impacts of each CCS are different for each crop, as crops respond with different yield variations according to each threshold of rainfall and temperature variation. The range of column presented in Table 7 shows the maximum yield variation ( $\mathrm{kg} \mathrm{ha}^{-1}$ year $^{-1}$ ), observed between CCS, providing a measurable estimate of how crop yield responds under considered climate variation conditions.
In the subsequent analysis, yield losses (\%) were calculated taking the estimated yields for the reference period (Table 6), providing a more representative view of the 30-year averages than the crop ideal-conditions annual yields per hectare described in Table 5. Figs. 8and 9 summarize the estimated yield variation (\%) respectively for future periods 1 (2011-2040) and 2 (2041-2070) in comparison with the yields estimated for reference period climate (1961-1990) for all the climate change scenarios (CCS 1-5) studied.

Both future periods will experience yield losses under all climate change scenarios considered, and, for future period 2, the yield losses predicted by the models will be more than double for the majority of the crops considered in this study.

Table 7

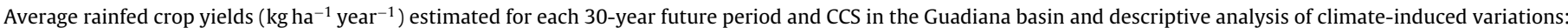
variation range $\left(\mathrm{kg} \mathrm{ha}^{-1}\right.$ year $\left.^{-1}\right), \mathrm{SD}=$ standard deviation $\left(\mathrm{kg} \mathrm{ha}^{-1}\right.$ year $\left.^{-1}\right)$ between the 5 generated CCS outputs.

\begin{tabular}{|c|c|c|c|c|c|c|c|c|}
\hline Future period & & CCS-1 & CCS-2 & CCS-3 & CCS-4 & CCS-5 & Range & SD \\
\hline Period 1 & Winter wheat & 3029.6 & 2909.4 & 2925.5 & 2948.8 & 2973.1 & 120.2 & 47.0 \\
\hline \multirow[t]{7}{*}{$(2011-2040)$} & Winter fodder ${ }^{*}$ & 5483.9 & 5336.1 & 5355.9 & 5384.6 & 5414.4 & 147.8 & 57.9 \\
\hline & Sunflower & 747.1 & 719.0 & 717.0 & 720.6 & 724.5 & 30.1 & 12.3 \\
\hline & Grain legume & 3294.7 & 3270.4 & 3267.8 & 3308.2 & 3295.6 & 40.4 & 17.5 \\
\hline & Pastures & 1053.7 & 1031.1 & 1031.9 & 1035.5 & 1030.8 & 22.9 & 9.7 \\
\hline & Olive & 1684.1 & 1674.1 & 1641.7 & 1666.6 & 1627.4 & 56.7 & 23.5 \\
\hline & Grapevine & 4818.1 & 4806.7 & 4794.4 & 4796.7 & 4789.8 & 28.3 & 11.3 \\
\hline & Almond & 661.1 & 615.4 & 619.2 & 633.2 & 635.1 & 45.7 & 18.0 \\
\hline Period 2 & Winter wheat & 2917.8 & 2792.1 & 2784.5 & 2781.8 & 2718.1 & 199.6 & 72.8 \\
\hline \multirow[t]{7}{*}{$(2041-2070)$} & Winter fodder ${ }^{*}$ & 5346.4 & 5191.8 & 5182.5 & 5179.1 & 5100.8 & 245.6 & 89.5 \\
\hline & Sunflower & 707.3 & 679.9 & 657.6 & 654.1 & 648.2 & 59.1 & 24.3 \\
\hline & Grain legumes & 3273.1 & 3218.0 & 3244.1 & 3288.2 & 3200.2 & 88.0 & 36.7 \\
\hline & Pastures & 1022.8 & 988.9 & 979.8 & 985.1 & 965.5 & 57.3 & 21.2 \\
\hline & Olive & 1616.7 & 1576.9 & 1527.8 & 1529.4 & 1495.5 & 121.2 & 47.6 \\
\hline & Grapevine & 4741.5 & 4718.4 & 4625.6 & 4641.0 & 4634.0 & 115.9 & 53.7 \\
\hline & Almond & 606.0 & 552.5 & 547.4 & 550.4 & 519.0 & 87.0 & 31.5 \\
\hline
\end{tabular}

* Winter fodder reference yield (dry matter biomass) was estimated considering its relation (Eq. (4)) with winter wheat grain yield. 


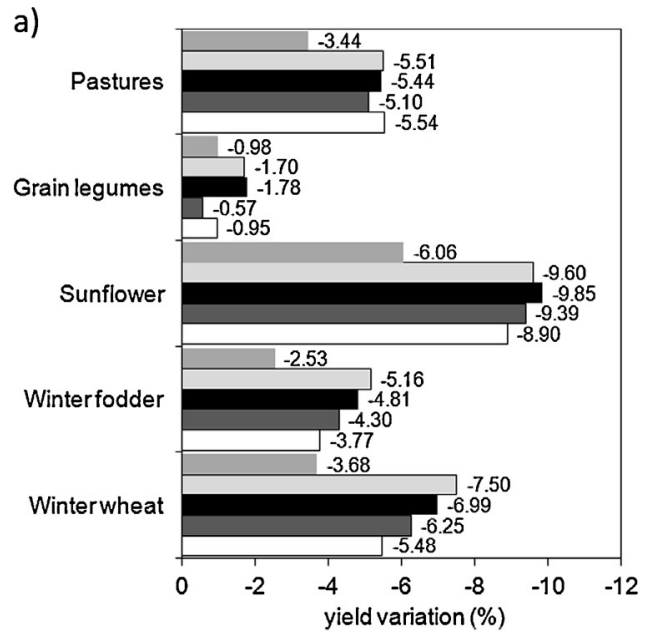

$\square \operatorname{ccs}-1 \square \operatorname{CCS}-2$ accs -3 accs -4 accs -5

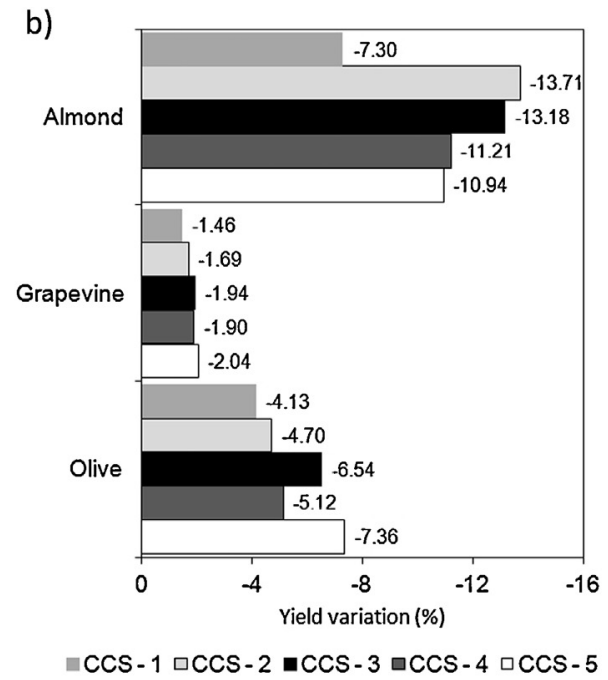

Fig. 8. Yield variation (\%) for each crop and CCS for future period 1 in comparison with the historic reference period for: (a) herbaceous crops, and (b) woody crops.
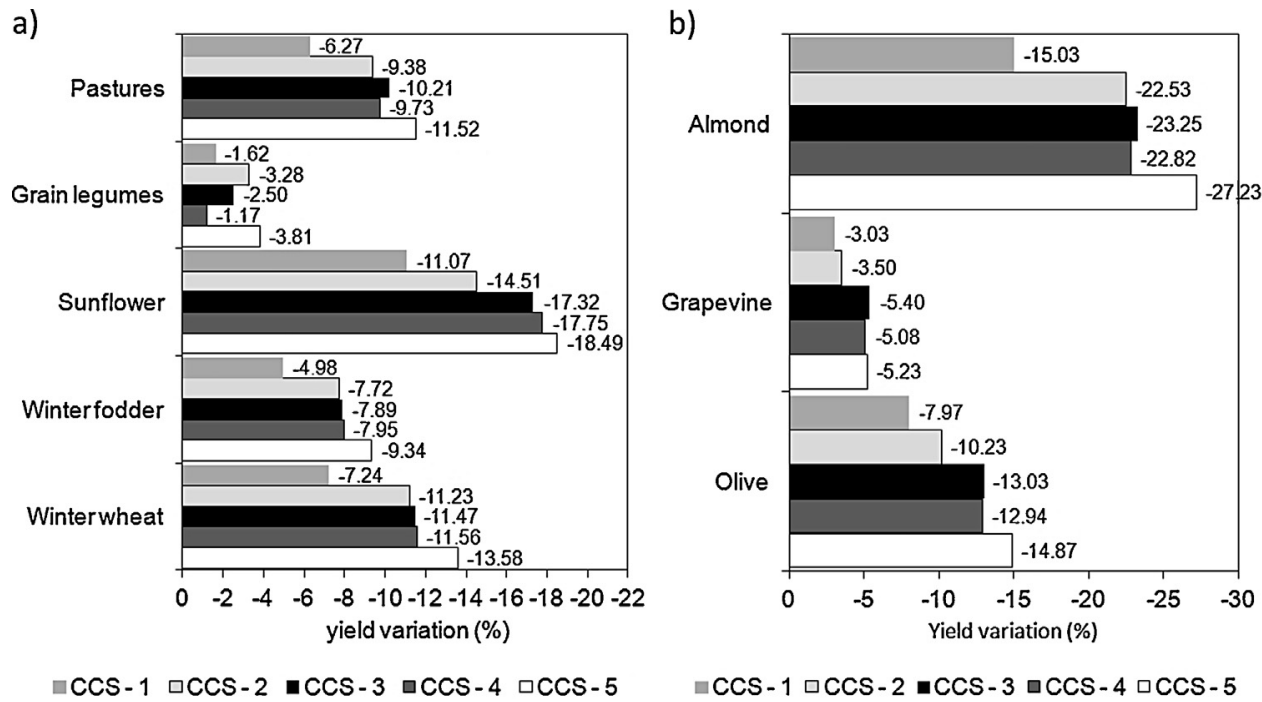

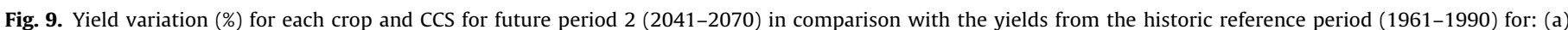
herbaceous crops, and (b) woody crops.

Grain legumes seem to be the less vulnerable crops to the climate change scenarios (CCS 1 to 5 ) showing smaller yield variations as compared with the historic period. This may suggest that shortcycle winter crops may be more viable under climate change than longer cycle crops as winter wheat or permanent crops as pastures. The results also show that, within the herbaceous crops, sunflower and winter wheat are the most susceptible to yield losses in future climate. Sunflower estimated yield losses lie between 6 and $9.8 \%$ for the 2011-2041 period, and 11 to $18.5 \%$ in the $2041-2070$ period. Woody rainfed crop results show that almond estimated yields can exhibit greater losses than grapevine and olive, featuring estimated yield losses of as much as $13.7 \%$ under climate change scenario CCS 2 for future period 1 and $27.2 \%$ under CCS 5 for future period 2 .

Within the rainfed livestock feeding crops (pastures, grain legumes and winter fodder) the maximum estimated yield losses correspond to natural grown pastures under CCS 5 with a 5.5\% loss in future period 1 and $11.5 \%$ in future period 2 . Winter fodder and pastures have different yield responses under different climate change scenarios because, while pastures exhibit higher losses under CCS 5 in both future periods, winter fodder yield is more adversely affected by climate change scenario CCS 2 for future period 1 and CCS 5 for future period 2, suggesting that winter fodder yield is more susceptible to temperature increase, given the thresholds (Table 2) as CCS 2 and 5 share the same rainfall variation but different air temperature thresholds.

\section{Conclusions}

The yields of rain-fed crops in southern Portugal, namely the Guadiana basin area, are already highly limited by the variability of the Mediterranean climate and the expected climate changes for the next decades can affect yields more deeply.

The results display evidence that a general decrease in crop yields can be expected for the main representative rainfed crops in future period 1 (2011-2040), and most intensely under future period 2 (2041-2070). Given the climate bracketing conditions of the five different climate change scenarios studied (CCS 1-5), the resulting estimated yield losses can clearly be related with the different bracketing conditions of rainfall decrease and air temperature increase applied to the future climate scenarios, as these climate features play the most determinant role within the soil 
water balance approach to meet crop water requirements under rainfed conditions.

Because each crop responded differently to the climate scenarios adopted for running the water balance models, some crops showed higher average yield losses than others. Sunflower and winter wheat were the herbaceous crops that exhibited higher estimated yield losses under the future climate scenarios analysed, while livestock crops showed less severe yield losses in comparison with the reference historical period. Almond was the woody crop that showed higher yield losses under the effects of the tested climate change scenarios, and, although grapevine and olive also exhibited significant yield losses, the overall results suggest that these crops will remain viable in rainfed conditions under the simulated future climate projection scenarios.

This study provided a climate-based simplified quantitative approach to rainfed yield estimation and allowed for the assessment of the possible outcomes of rainfed agriculture in the Guadiana river basin. However, it is important to underline that future outcomes are also dependent on crop-specific management practices, and, most important, on soil quality preservation. Rainfed crops are also very dependent on additional agricultural management practices not addressed within this study, but whose relative impacts on yield can potentially go beyond climate induced impacts, setting the need for farmers to seek out and endorse management practices optimization. Although rainfed crops have a more limited range of possible decision options regarding management, practices such as pruning (grapevine and olive) and effective disease control, if properly implemented, can help crops to achieve better yields, both in terms of quantity and quality. Herbaceous crops grown under rainfed conditions can also benefit from improved management practices aimed at partially counteracting some of the climate change's negative effects, mostly by way of optimized fertilization and the more meticulous scheduling of sowing and tillage procedures.

\section{Acknowledgments}

This work has been possible thanks to the Fundação para a Ciência e Tecnologia (FCT) through the research project ref. PTDC/AAC-AMB/115587/2009 "Developing a methodology for integrating the effects of climate change in water resources management applied to a Portuguese river basin", with the participation of the Faculty of Engineering of the University of Porto (FEUP, Project leader), the Institute of Agricultural and Environmental Sciences of the University of Évora (ICAAM-UE),the Operative Centre of Irrigation Technology (COTR), and of researchers from the National Oceanic and Atmospheric Administration (NOAA) and the Bureau of Reclamation, from USA.

\section{References}

Adam, J.C., Lettenmaier, D.P., 2003. Adjustment of global gridded precipitation for systematic bias. J. Geophys. Res. 108, 1-14.

Allen, R., Pereira, L.S., Raes, D., Smith, M., 1998. Crop evapotranspiration: guidelines for computing crop water requirements. In: FAO Irrigation and Drainage, Paper No. 56. Rome, Italy, 300pp.
Clarke, D., 1998. CROPWAT for Windows: user guide. FAO, Rome.

Droogers, P., Allen, R.G., 2002. Estimating reference evapotranspiration under inaccurate data conditions. Irrigat. Drain. Syst. 16 (1), 33-45, http://dx.doi.org/10. 1023/A:10/15508322413.

Doorenbos, J., Kassam, A., 1979. Yield response to water. In: FAO Irrigation and Drainage Paper 33. Rome.

Doorenbos, J., Pruitt, W.O., 1977. Guidelines for predicting crop water requirements. In: FAO Irrigation and Drainage paper no. 24. FAO, Rome.

Filippo, G., Piero, L., 2008. Climate change projections for the Mediterranean region. Global Planet 63 (September (2-3)), 90-104, 0921-8181.

Hargreaves, G.H., Samani, Z.A., 1985. Reference crop evapotranspiration from temperature. Appl. Eng. Agric. 1, 96-99.

Instituto Nacional de Estatística, (INE), 2011. Recenseamento Agrícola 2009. Instituto Nacional de Estatística, (INE).

Fernández, J.E., Moreno, F., Girón, I.F., Blázquez, O.M., 1997. Stomatal control of water use in olive tree leaves. Plant Soil 190 (Mar. (2)), 179-192.

Maurer, E.P., Adam, J.C., Wood, A.W., 2009. Climate model based consensus on the hydrologic impacts of climate change to the Rio Lempa basin of Central America. Hydrol. Earth Syst. Sci. 13, 183-194.

Meehl, G.A., Covey, C., Delworth, T., Latif, M., McAvaney, B., Mitchell, J.F.B., Stouffer, R.J., Taylor, K.E., 2007. The WCRP CMIP3 multi-model dataset: a new era in climate change research. Bull. Am. Meteorol. Soc. 88, 1383-1394.

Reclamation, 2009. Climate Change and Hydrology Scenarios for Oklahoma Yield Studies. U.S. Department of the Interior, Bureau of Reclamation, Washington D.C.

Reclamation, 2011. West-Wide Climate Risk Assessments: Bias-Corrected and Spatially Downscaled Surface Water Projections. U.S. Department of the Interior, Bureau of Reclamation, Washington D.C.

Rosegrant, M.W., Cai, X., Cline, S.A., Nakagawa, N., 2002. The role of rainfed agriculture in the future of global food production. In: EPTD Discussion Paper No. 90. International Food Policy Research Institute (IFPRI), Washington, DC, USA.

Samani, Z.A., Pessarakli, M., 1986. Estimating potential crop evapotranspiration with minimum data in Arizona. Trans. ASAE (29), 522-524.

Santos, M., Maia, J., 2005. Calibração da ETo estimada pelo método de Hargreaves e tina evaporimétrica classe A. In: Paper Published in the Proceedings of the I Congresso Nacional de Rega e Drenagem, Beja, 2005.

Santos, F.D., Miranda, P., 2006. Alterações Climáticas em Portugal. Cenários, Impactos e Medidas de Adaptação-Projecto SIAM II. Gradiva, Lisboa.

Serralheiro, R., Carvalho, M., Corte-Real, J., Toureiro, C., 2010. Sistema de Previsão e Gestão de Secas (SPGS)-Relatórios 1 a 4, 2009 e 2010. ICAAM, Universidade de Évora.

Shahidian, S., Serralheiro, R., Serrano, J., Teixeira, J.L., Naim, H., Santos, F.L., 2012. Hargreaves and other reduced-set methods for calculating evapotranspiration. In: Irmak, Ayse (Ed.), Evapotranspiration-Remote Sensing and Modeling. In Tech, Europe, Rijeka, Croatia, ISBN 978-953-307-808-3, pp. 59-80, Chapter.

Steduto, P., Hsiao, T., Fereres, E., Raes, D., 2012. Crop yield response to water. In: FAO Irrigation and Drainage Papers No. 66. Rome, Italy, 516pp.

Stewart, J.I., Hagan, R.M., 1973. Functions to predict effects of crop water deficits. J. Irrig. Drain. Div. ASCE 99, 421-439.

Stewart, J.I., Danielson, R.E., Hanks, R.T., Jackson, E.B., Hagan, R.M., Pruitt, W.O., Franklin, W.T., Riley, J.P., 1977. Optimizing Crop Production through Control of Water and Salinity Levels in the Soil. Utah Water Research Lab. PR. 151-1, Logan, Utah, $191 \mathrm{pp}$.

Teixeira, J.L., 1994. ISAREG-Manual do Utilizador. Instituto Superior de Agronomia, Universidade Técnica de Lisboa, Lisboa.

Teixeira, J.L., Pereira, L.S., 1992. ISAREG, an irrigation scheduling model. ICID Bull. 41 (2), 29-48.

Valverde, P., Serralheiro, R., Carvalho, M., Shahidian, S., Rodrigues, C., 2014. Efeitos das alterações climáticas nas necessidades úteis de rega na bacia do Guadiana (Effects of climate change on crop net irrigation requirements in the Guadiana basin). Revista Recursos Hídricos 35 (1), 53-67 (Lisboa, APRH), DOI 105894/rh35 n1-4.

Vivas, E., Maia, R., 2010. A Gestão de Escassez e Secas Enquadrando as Alterações Climáticas. Revista Recursos Hídricos 31 (1), 25-37 (Março, APRH).

Vivas, E., Silva, C., Correia, L., Maia, R., 2010. Definição de unidades de análise para prevenção, avaliação e gestão de situações de seca. Aplicação ao caso da bacia do rio Guadiana. In: em Actas da Conferência $10^{\circ}$ Congresso da Água-Marcas d'Água, Algarve, Março de 2010, ISBN 978-972-99991-9-2.

Wood, A.W., Leung, L.R., Sridhar, V., Lettenmaier, D.P., 2004. Hydrologic implications of dynamical and statistical approaches to downscaling climate model outputs. Clim. Change 62, 189-216. 